\title{
Environmental predictors of sediment denitrification rates within restored green-lipped mussel Perna canaliculus beds
}

\author{
Mallory A. Sea*, Simon F. Thrush, Jenny R. Hillman \\ Institute of Marine Science, University of Auckland, Auckland 1142, New Zealand
}

ABSTRACT: Benthic processes in coastal marine environments can enhance the natural removal of bioreactive nitrogen through denitrification (DNF), a valuable ecosystem service as nutrient over-enrichment intensifies globally. Enhancing ecosystem services is an important justification for restoring coastal ecosystems, and while it is known that epifaunal bivalves (oysters or mussels) are capable of influencing nitrogen cycling, empirical measurement of the role of particular species across a range of environmental conditions is missing. Bivalves within shellfish beds are not uniformly distributed and thus clumps and empty patches within restored beds may differentially impact DNF given the importance of local biogeochemistry. This study reports DNF and respiration rates in 4 restored beds that vary in sediment composition, while identifying which ecological and biogeochemical factors best explain the observed variability in measured fluxes. We deployed benthic chambers in sediments with and without mussels at these sites, and measured net $\mathrm{N}_{2}$ fluxes through membrane inlet mass spectroscopy. Sediment organic matter proved to be the most significant predictor of DNF rates in regression tree and random forest models, suggesting that biodeposition by green-lipped mussels enhances nitrogen removal at these sites and that these effects occur across beds despite differences in mussel density. Greatest DNF rates corresponded to lower sediment chlorophyll a concentrations and higher nitrate/nitrite effluxes measured within chambers. Determining the influence of subtidal mussel restoration on significant sediment processes informs future restoration efforts aiming to maximise this nitrogen removal service, while providing insights on underrepresented oligotrophic systems of the southern hemisphere.

*Corresponding author: msea579@aucklanduni.ac.nz

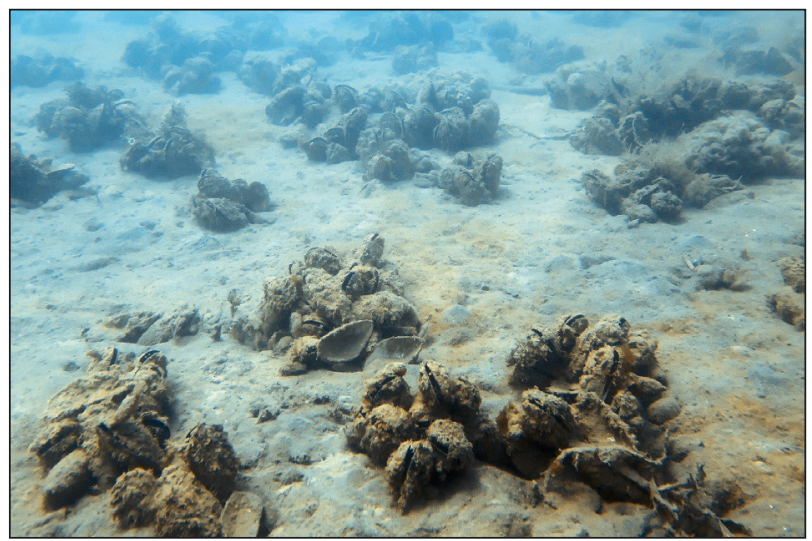

Nitrogen removal rates are consistent despite patchiness in restored beds of green-lipped mussels, highlighting the upscaling-role of mussels in seafloor biogeochemistry.

Photo: Jenny Hillman

KEY WORDS: Soft sediments - Benthic-pelagic coupling · Benthic fluxes · Nitrogen · Subtidal . Restoration · Bivalves

\section{INTRODUCTION}

Nitrogen loading is commonly associated with eutrophication and the degradation of coastal environments, as nitrogen typically limits algal growth and primary production (Howarth \& Marino 2006), but in excess, can lead to toxic algal blooms (Paerl 1997, Anderson et al. 2002) and hypoxic conditions (Diaz \& Rosenberg 2008). Anthropogenic nitrogen

(C) The authors 2021. Open Access under Creative Commons by Attribution Licence. Use, distribution and reproduction are unrestricted. Authors and original publication must be credited. 
enrichment is currently accelerating at alarming rates (Galloway et al. 2004, 2008, Kuypers et al. 2018), and therefore has growing consequences for coastal oceans and the services they provide (Nixon 1998, Howarth \& Marino 2006). As humans continue to generate bioreactive nitrogenous compounds (e.g. ammonium and nitrate available for biological uptake) and fail to control excessive nitrogen inputs to ecological systems, the capacity of coastal environments to remove excess nitrogen becomes of even greater value to humans. However, this process is currently not well understood. The fate of over $60 \%$ of global reactive nitrogen is unknown (Galloway et al. 2008), but a significant portion of this nitrogen is thought to be denitrified in coastal to continental shelf sediments (Middelburg et al. 1996, Seitzinger et al. 2006). It is thought that coastal marine environments are capable of removing half (Seitzinger 1988) to over $80 \%$ (Galloway et al. 2003) of terrestrial nitrogen inputs through the denitrification (DNF) process. Driven by facultative anaerobic bacteria, DNF converts bioavailable, inorganic nitrogen (in the forms of nitrite and nitrate) to molecular dinitrogen gas $\left(\mathrm{N}_{2}\right)$ and nitrous oxide $\left(\mathrm{N}_{2} \mathrm{O}\right)$, resulting in the net removal of this nutrient from the system (Thrush et al. 2013, Humphries et al. 2016). It is estimated that estuaries and coastal shelf regions currently remove $24 \mathrm{Tg}$ of reactive nitrogen each year (Galloway et al. 2004), making DNF a valuable service provided by coastal soft sediments.

Previous work has shown that bivalves are capable of enhancing the DNF process (e.g. Christensen et al. 2003, Piehler \& Smyth 2011, Carlsson et al. 2012, Kellogg et al. 2013, Humphries et al. 2016). However, bivalve populations are under pressure in many coastal ecosystems as a result of multiple stressors, including over-harvesting, physical disturbance, sedimentation, contamination, and eutrophication (e.g. Peterson et al. 1994, Cook et al. 2000, Kirby 2004, McLeod et al. 2012, Thrush et al. 2021). Restoration projects are underway worldwide to restore these populations and regain ecosystem services associated with shellfish reef formation (zu Ermgassen et al. 2020), and shellfish restoration could be an effective tool to enhance this nitrogen removal service limiting degradation in coastal ecosystems. In short, subtidal epifaunal bivalve populations remove resuspended microphytes and phytoplankton from the water column as a result of their filter feeding processes (Dame 2012). Bivalves then deposit this organic matter, sourced across a range of spatial scales depending on hydrodynamic regimes, onto the seafloor in the form of faeces and pseudofaeces (herein referred to as biodeposits; Newell 2004). The remineralisation of these biodeposits results in ammonium driving nitrification in surface-layer aerobic sediments (Kellogg et al. 2013). The nitrate produced from this process typically drives DNF at oxic/anoxic interfaces and results in the conversion of biologically reactive forms of nitrogen into inert $\mathrm{N}_{2}$ gas, effectively removing nitrogen from the system. While enhanced sediment DNF is predicted as a result of bivalve restoration projects in highly eutrophic systems (e.g. Cerco \& Noel 2007), studies in oligotrophic systems are rare (Vieillard et al. 2020), and there is a severe lack of in situ studies involving bivalves and DNF.

Laboratory studies (e.g. Kellogg et al. 2013, Smyth et al. 2018) and one known in situ study (Humphries et al. 2016) have shown that bivalve restoration projects on the seafloor can enhance sediment DNF rates as compared to nearby sediments without any bivalve presence. While these studies determine how nitrogen removal varies spatially and/or temporally in sediments with and without the presence of shellfish, the complex interactions between environmental factors that drive enhanced DNF within these beds remain less well understood. In addition, the spatial structure of mussels within mussel beds is influenced by a multitude of factors, including location within an estuary, position along tidal height gradients, differential predation, local hydrodynamics, etc. (Commito \& Dankers 2001). The role of these heterogeneous spatial arrangements of clumps and bare patches within mussel beds has yet to be explored, but is important in estimating the overall contribution of restored beds to DNF. We have observed this patchiness in the distribution of mussels at our restoration sites, which led us to question how the quantity of trapped sediment organic matter (SOM) from both allochthonous sources and local biodeposits influences DNF rates within individual beds.

Bivalves involved in benthic-pelagic coupling and the resultant organic material accumulated in restored beds are predicted to enhance sediment DNF, but the effect of organic matter deposits on nitrogen mineralisation pathways ultimately depends on multiple factors, including the type and quantity of material deposited (Eyre et al. 2013), as well as local hydrodynamics and benthic mineralisation rates in coastal waters (Prins et al. 1998). In addition, differing sediment characteristics will likely influence the accumulation of organic-rich biodeposits and transport of nutrients, as changes in suspended sediment concentration (associated with a grain size gradient) affect bivalve clearance rates (Hawkins et al. 1999) and the quality of biodeposits produced (Iglesias et 
al. 1996). Species diversity and varying abundances of benthic macrofauna (typically polychaetes and molluscs) will also affect particle movement and water transport as a result of feeding activity and bioturbation (Quintana et al. 2007, Douglas et al. 2017, O'Meara et al. 2020). Together, these environmental variables and the complex interactions among them affect sediment biogeochemistry and likely regulate DNF in different restoration sites. A greater understanding of factors that significantly influence nitrogen removal rates will aid in our selection of future mussel bed restoration locations that seek to enhance this service.

These gaps in our understanding together with a paucity of research on restored mussel beds provide an opportunity to explore the complexities of nitrogen cycling in coastal ecosystems. In this study, we measured a suite of environmental factors associated with sediment DNF rates in 2 muddy and 2 sandy subtidal restoration sites of New Zealand's endemic greenlipped mussel Perna canaliculus. To determine if DNF rates varied within the larger mussel bed complex, benthic chambers were deployed at each site enclosing mussel clumps or bare sediments between bivalve patches. Net gas fluxes across the sedimentwater interface were measured using ratios of dinitrogen to argon $\left(\mathrm{N}_{2} / \mathrm{Ar}\right)$ through membrane inlet mass spectroscopy (MIMS). The importance of a representative suite of environmental factors in explaining flux variability was then explored using decision trees and random forest algorithms. We hypothesised that organic-rich biodeposits trapped within mussel beds would be most important in stimulating microbial activity associated with enhanced sediment DNF, but that the strength of these effects would vary with site characteristics.

\section{MATERIALS AND METHODS}

\subsection{Study area}

Restored mussel beds were created by transplanting roughly $10 \mathrm{t}$ of adult green-lipped mussels sourced from a mussel farm to desired soft-sediment locations at similar depths $(5-10 \mathrm{~m})$, forming beds approximately $10 \mathrm{~m}^{2}$ in size. At the time of this study, beds were 2-3 yr old and exhibited different spatial patterns (see Text S1 in the Supplement at www.intres.com/articles/suppl/m667p001_supp.pdf). Restoration sites were initially identified to capture environmental variation associated with sediment grain size, $\mathrm{SOM}$, and macrofaunal assemblages. Two of these re- stored beds were located near the mouth of Mahurangi Harbour (Lagoon Bay and Pukapuka), and 2 were outside the harbour adjacent to nearshore islands (Motuora and Motoketekete; Fig. 1). Our 2 harbour sites were characterised by finer, siltier sediments more easily resuspended in the water column, whereas the island sites exhibited a sandy substrate with less resuspended material. Chosen sites therefore provided differences in both a suite of environmental characteristics and the effect of mussel clumps.

\subsection{Sample collection}

This study was conducted in March and April 2019. Using SCUBA, benthic chambers (e.g. Lohrer et al. 2004, O'Meara et al. 2020) were placed within restored beds over sediments containing mussel clumps. To capture spatial variability and account for bed patchiness, a number of chambers without mussels (but within bed boundaries) were also deployed in this study. Chambers $\left(0.25 \mathrm{~m}^{2}\right.$ each) were pushed into the sediment to a pre-marked line $7 \mathrm{~cm}$ from the chamber base, so that all chambers held 411 of nearbed seawater at the start of the incubation. A total of 12 chambers were deployed at 3 sites (Motuora,

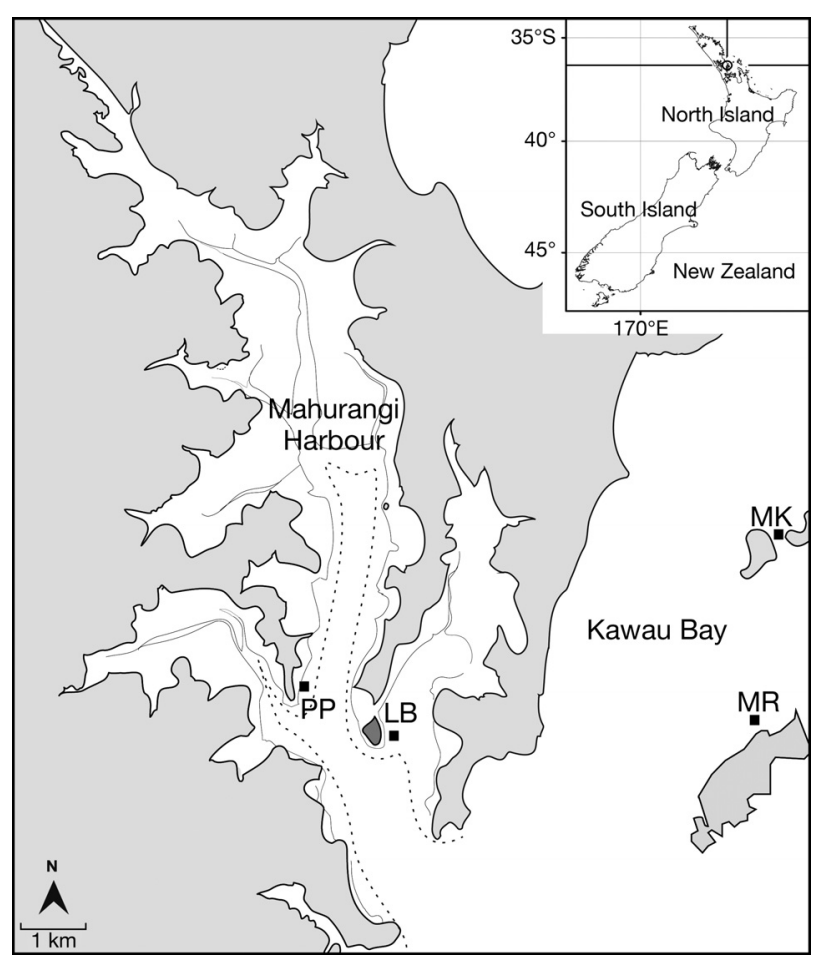

Fig. 1. Location of study sites in Mahurangi Harbour and Kawau Bay, New Zealand. LB: Lagoon Bay; PP: Pukapuka; MR: Motuora; MK: Motoketekete 
Motoketekete, and Pukapuka; beds roughly $10 \mathrm{~m}^{2}$ each), while 9 chambers were deployed at the smaller Lagoon Bay bed $\left(\sim 7 \mathrm{~m}^{2}\right)$. Photos were taken of each chamber, and the number of mussels was recorded (Table S1). One site was sampled per day.

Each benthic chamber was equipped with a miniDOT optical oxygen logger (Precision Measurement Engineering), which recorded dissolved oxygen in the chamber water every minute, and a pump which recirculated chamber water for $5 \mathrm{~s}$ at $30 \mathrm{~s}$ intervals. Chamber lids were carefully sealed while underwater to ensure there were no gas bubbles. Chambers were then covered with black polyethylene to omit incoming light. These dark incubations mean we omit the role of microphyte production, but this avoided complications associated with bubble formation in light chambers due to photosynthesis as well as complicating comparisons due to variation in photosynthetically active radiation due to changes in weather and water clarity.

To determine net fluxes across the sediment-water interface, samples for MIMS and dissolved inorganic nutrient analysis (nitrate/nitrite, reactive phosphorus, and ammonium concentrations, herein referred to as $\mathrm{NO}_{\mathrm{x}}{ }^{-}, \mathrm{PO}_{4}{ }^{3-}$, and $\mathrm{NH}_{4}{ }^{+}$) were taken from the chamber port using 2 syringes (60 ml capacity) immediately after covering chamber lids, taking care to remove any air bubbles from the syringes beforehand. Water samples were taken again from each chamber at the end of the incubation period (approximately $3 \mathrm{~h}$ ). At the end of the incubation period, the chamber lids were removed and 2 sediment syringe cores (3 cm length, $1.9 \mathrm{~cm}$ diameter) were taken from within each chamber for chlorophyll a (chl a), SOM, and grain size analysis. Avoiding mussel clumps, an additional $10 \mathrm{~cm}$ diameter, $10 \mathrm{~cm}$ deep sediment core was taken from within each chamber to assess dominant macrofauna present at each site.

Immediately after collection, water samples for nutrient analysis were filtered through Whatman GF/F filters $(0.7 \mu \mathrm{m}$ pore size) and stored on ice before being transferred to the lab and frozen. Each unfiltered MIMS sample was transferred into 2 gas-tight $12 \mathrm{ml}$ exetainer vials (for a total of 4 per chamber) and poisoned with $\mathrm{ZnCl}_{2}$ to stop biological activity. MIMS samples were stored below collection temperature, but above freezing. These samples were transferred to the lab and kept at $4^{\circ} \mathrm{C}$ pending analysis. Sediment samples for SOM, grain size, and chl a content were kept on ice in the dark and frozen at the lab until later analysis. Macrofauna cores were sieved (500 $\mu \mathrm{m}$ mesh) with seawater and contents transferred into storage containers with $70 \%$ isopropyl alcohol stained with rose bengal. Macrofauna were later sorted and classified to the lowest practical taxonomic group. For each core, the total number of macrofauna present, total number of known bioturbators present (total bioturbators), and total number of species present (species richness) were recorded for use in later analyses.

\subsection{Sediment characterisation}

SOM was determined by loss on ignition (Ball 1964). Sediments were left in a $60^{\circ} \mathrm{C}$ oven, dried for $48 \mathrm{~h}$, and then weighed before and after combustion at $500^{\circ} \mathrm{C}$ for $10 \mathrm{~h}$.

To determine sediment grain size, homogenised sediment samples ( 20 g) from each chamber were digested with $50 \mathrm{ml}$ of $6 \% \mathrm{H}_{2} \mathrm{O}_{2}$ and periodically mixed over a $48 \mathrm{~h}$ time period. Samples were then rinsed of hydrogen peroxide and sat overnight in $\sim 15 \mathrm{ml}$ of $5 \%$ Calgon (a dispersing agent for sediment particles) prior to grain size analysis with a Malvern Mastersizer 3000 (ATA Scientific).

To assess the standing stock of the microphytobenthos (MPB), chl a was extracted from $1 \mathrm{~g}$ of freezedried sediment samples with $3 \mathrm{ml}$ of $90 \%$ acetone. Optical densities of extracts were measured at 664, 665, and $750 \mathrm{~nm}$ with a UV-Vis spectrophotometer (Thermo Scientific, Multiskan Sky) before and after acidification with hydrochloric acid $(0.1 \mathrm{ml}$ of $0.1 \mathrm{M}$ $\mathrm{HCl}$ ). Values at $750 \mathrm{~nm}$ were subtracted from values at 664 and $665 \mathrm{~nm}$ to correct for turbidity in samples. Sediment chl a content was calculated using equations from Lorenzen (1967) based on 90\% acetone extraction:

$$
\begin{aligned}
& \text { Chl a content }\left(\mu \mathrm{g} \mathrm{chl} \mathrm{a} \mathrm{g}^{-1} \text { sediment }\right)= \\
& \frac{11 \times 2.43 \times\left(E_{664 b}-E_{665 a}\right) \times V_{e}}{D}
\end{aligned}
$$

where $E_{664 b}$ is the corrected absorbance at $664 \mathrm{~nm}$ before acidification, $E_{665 a}$ is the corrected absorbance at $665 \mathrm{~nm}$ after acidification, $V_{e}$ is the volume of the extractant (ml), and $D$ is the dry weight of sediment $(\mathrm{g})$.

\subsection{Flux analysis}

To determine if net DNF rates varied between mussel clumps and the spaces between them, seawater samples were analysed on a quadrupole membrane inlet mass spectrometer (with Pfeiffer Vacuum Prisma Plus QMG220 M1 QMS, Bay Instruments) using the MIMS technique (Kana et al. 1994). This 
high precision $(<0.05 \%)$ method uses $\mathrm{N}_{2} / \mathrm{Ar}$ ratios to determine a net flux of $\mathrm{N}_{2}$ from all processes that form $\mathrm{N}_{2}$ (DNF, anaerobic ammonium oxidation) or use $\mathrm{N}_{2}$ (nitrogen fixation). With this technique, a net positive $\mathrm{N}_{2}$ flux indicates that DNF dominates, while a net negative $\mathrm{N}_{2}$ flux indicates that nitrogen fixation dominates. It should be noted that, while anaerobic ammonium oxidation produces $\mathrm{N}_{2}$ gas, the contribution of this process to overall nitrogen removal in estuarine environments is quite minor globally (5-14\% on average; Hou et al. 2015) and goes undetected at high-salinity, low-nutrient sites ( $<6 \mu \mathrm{M} \mathrm{NO}_{3}{ }^{-}$; Rich et al. 2008) similar to those studied here (see Table S2 for a summary of additional environmental characteristics recorded). We therefore assume that all nitrogen removal measured in this study is the direct consequence of DNF, but that further nitrogen removal (not estimated) may be occurring as a result of burial within sediments.

With known incubation times for each chamber, fluxes were calculated as the difference between initial and final concentrations and corrected for volume and surface area of the chamber to obtain a flux in $\mu \mathrm{mol} \mathrm{m} \mathrm{m}^{-2} \mathrm{~h}^{-1}$ (e.g. Eyre et al. 2002, O'Meara et al. 2020). This was done for both $\mathrm{N}_{2}$ and $\mathrm{O}_{2}$ fluxes. $\mathrm{O}_{2}$ fluxes calculated from the MIMS technique were then compared to data obtained from the oxygen loggers placed in benthic chambers. Dissolved oxygen data from these loggers were similarly graphed, and the slope of the linear portion of the line was used to calculate a flux rate that was also corrected for volume and area of the chamber space. Even though $\mathrm{O}_{2}$ fluxes were found to be comparable, the manual truncation method described above to calculate $\mathrm{O}_{2}$ fluxes has been critiqued for introducing subjectivity into analysis (see Olito et al. 2017), and data from MIMS was instead used in further calculations. All chambers with mussels were examined for hypoxia $\left(<2.0 \mathrm{mg} \mathrm{O}_{2} \mathrm{l}^{-1}\right)$ at the end of the $3 \mathrm{~h}$ incubation period, and chambers with oxygen concentrations below this threshold were discarded from further analysis.

Nutrient samples were analysed using a Lachat Autosampler (ASX-260 Series) flow injection analyser (method detection limits of $0.032,0.05$, and $0.071 \mu \mathrm{mol} \mathrm{l} \mathrm{l}^{-1}$ for $\mathrm{PO}_{4}{ }^{3-}, \mathrm{NH}_{4}{ }^{+}$, and $\mathrm{NO}_{\mathrm{x}}{ }^{-}$, respectively), with standard methods for analysis of seawater nutrients. Values were corrected using calibration standards, and net fluxes were calculated by taking the difference between final and initial concentration values and dividing by chamber incubation time while accounting for volume and area of sediment enclosed by the chamber.

\subsection{Statistical analysis}

The effects of site, mussel presence/absence, and their interaction on measured fluxes and varying environmental characteristics were investigated using 2-way ANOVA, followed by Tukey's tests for post hoc comparisons (results summarised in Table S3). Assumptions of normality and homogeneity of variance were checked using the statistical package 's20x' (Balemi et al. 2021) in R (version 3.6.1; R Core Team 2019). Q-Q plots, Shapiro-Wilk tests, and Levene's tests were used to check assumptions, and values were log-transformed where necessary. Significance levels were set to $\alpha=0.05$, and standard errors (SE) were used to assess the precision of mean values, unless otherwise stated.

To determine which of the measured environmental variables explained the most variation in measured fluxes within mussel beds, we used machine learning statistical techniques involving regression trees and random forest models. These non-parametric approaches have gained popularity in ecological sciences (e.g. Evans \& Cushman 2009, Ray et al. 2020, Smith DiCarlo et al. 2020) and are valued for their ability to cope with complex interactions, non-linear relationships, and unbalanced experimental designs, while producing graphical outputs that are easily interpreted and reveal relationships that often go unrecognised using more traditional statistical techniques (De'ath \& Fabricius 2000).

We used the 'rpart' package (Therneau \& Atkinson 2019) in $\mathrm{R}$ to create a decision tree which split the full data set into multiple groups (each split creating the lowest possible within-group variation) until predetermined end points were met (in this case, 4 minimum observations required in a node for a split to be attempted and at least 2 observations in any terminal node; complexity parameter $=0.014)$. Eleven explanatory variables were used to predict net $\mathrm{N}_{2}$ fluxes in regression trees and random forests: $\mathrm{SOM}$, oxygen fluxes, nutrient fluxes $\left(\mathrm{NO}_{\mathrm{x}}{ }^{-}, \mathrm{PO}_{4}{ }^{3-}, \mathrm{NH}_{4}{ }^{+}\right)$, total macrofauna abundance, total number of bioturbators, species richness, chl a content, total number of mussels per chamber, and percentage mud content. Variables near the root (top) of the tree were considered most influential in classifying the response variable into various terminal nodes (in this case, net $\mathrm{N}_{2}$ fluxes). Interactions between explanatory variables were conceptualised as subsequent splits, dependent on the results of decisions at nodes higher in the tree. 
Table 1. Summary of sediment characteristics between sites, separated by chambers with and without mussels. Mud is comprised of silt + clay $(<63 \mu \mathrm{m})$. Medium sand is between 250 and $500 \mu \mathrm{m}$, and coarse sand is $>500 \mu \mathrm{m}$. SOM: sediment organic material. PP: Pukapuka; LB: Lagoon Bay; MR: Motuora; MK: Motoketekete. Different superscript letters denote significant differences between sites (post hoc Tukey's test, $\mathrm{p}<0.05$ ). Data represent the mean $\pm \mathrm{SE}$

\begin{tabular}{|cccccccc|}
\hline Site & $\begin{array}{c}\text { Chamber } \\
\text { contents }\end{array}$ & $\begin{array}{c}\text { Mud } \\
\text { content }(\%)\end{array}$ & $\begin{array}{c}\text { Medium } \\
\text { sand }(\%)\end{array}$ & $\begin{array}{c}\text { Coarse } \\
\text { sand }(\%)\end{array}$ & $\begin{array}{c}\text { SOM } \\
(\%)\end{array}$ & $\begin{array}{c}\text { Chl a content } \\
\left(\mu \mathrm{g}^{-1}\right)\end{array}$ & $\begin{array}{c}\text { Total number of } \\
\text { macrofauna core }^{-1}\end{array}$ \\
\hline PP & Mussels & $22.4 \pm 0.37^{\mathrm{a}}$ & $1.32 \pm 0.13^{\mathrm{a}}$ & $1.87 \pm 0.78^{\mathrm{a}}$ & $3.2 \pm 0.33^{\mathrm{a}}$ & $4.1 \pm 0.9^{\mathrm{a}}$ & $34.0 \pm 2.5^{\mathrm{a}}$ \\
& No mussels & $24.0 \pm 0.27^{\mathrm{a}}$ & $1.13 \pm 0.16^{\mathrm{a}}$ & $2.31 \pm 0.65^{\mathrm{a}}$ & $3.4 \pm 0.36^{\mathrm{a}}$ & $3.8 \pm 1.1^{\mathrm{a}}$ & $36.7 \pm 24.2^{\mathrm{a}}$ \\
LB & Mussels & $22.9 \pm 1.61^{\mathrm{a}}$ & $0.18 \pm 0.03^{\mathrm{a}}$ & $0.18 \pm 0.03^{\mathrm{a}}$ & $2.7 \pm 0.38^{\mathrm{b}}$ & $5.6 \pm 2.5^{\mathrm{bc}}$ & $34.0 \pm 11.4^{\mathrm{a}}$ \\
& No mussels & $20.0 \pm 1.56^{\mathrm{a}}$ & $0.42 \pm 0.10^{\mathrm{a}}$ & $0.71 \pm 0.18^{\mathrm{a}}$ & $2.3 \pm 0.02^{\mathrm{b}}$ & $8.5 \pm 1.1^{\mathrm{bc}}$ & $30.0 \pm 6.3^{\mathrm{a}}$ \\
MR & Mussels & $7.0 \pm 0.83^{\mathrm{b}}$ & $12.28 \pm 1.04^{\mathrm{b}}$ & $0.89 \pm 0.39^{\mathrm{a}}$ & $3.4 \pm 0.30^{\mathrm{a}}$ & $4.9 \pm 0.5^{\mathrm{ac}}$ & $107.3 \pm 13.6^{\mathrm{b}}$ \\
& No mussels & $4.6 \pm 0.10^{\mathrm{b}}$ & $12.14 \pm 0.28^{\mathrm{b}}$ & $1.45 \pm 0.69^{\mathrm{a}}$ & $2.9 \pm 0.17^{\mathrm{a}}$ & $3.2 \pm 2.7^{\mathrm{ac}}$ & $84.0 \pm 1.0^{\mathrm{b}}$ \\
MK & Mussels & $3.3 \pm 0.29^{\mathrm{c}}$ & $35.81 \pm 0.67^{\mathrm{c}}$ & $11.17 \pm 0.89^{\mathrm{b}}$ & $2.7 \pm 0.08^{\mathrm{b}}$ & $6.1 \pm 0.4^{\mathrm{c}}$ & $76.1 \pm 10.6^{\mathrm{b}}$ \\
& No mussels & $3.1 \pm 0.38^{\mathrm{c}}$ & $36.86 \pm 0.45^{\mathrm{c}}$ & $10.98 \pm 0.71^{\mathrm{b}}$ & $2.7 \pm 0.11^{\mathrm{b}}$ & $6.8 \pm 0.3^{\mathrm{c}}$ & $107.3 \pm 28.1^{\mathrm{b}}$ \\
\hline
\end{tabular}

It is recognised that regression trees and related predictive mapping methods typically undergo a 2step process: first, modelling the relationship between a response variable and a suite of explanatory variables from field measurements or observations; and second, using the generated model to predict the response variable at new sites given known values for the explanatory variables. As the goal of this study was to determine which predictor variables could best explain $\mathrm{N}_{2}$ flux variability in the single data set, it was only necessary to conduct the model creation process. We advise against the use of this descriptive model in predicting fluxes outside our wider study system, although conclusions gleaned from this investigation regarding the general importance of various environmental and biogeochemical factors can be used to inform the design of future experiments involving predictive modelling techniques.

A random forest algorithm ('randomForest' package; Liaw \& Wiener 2002) was used to rank the relative importance of explanatory variables used in this study. Random forest is an ensemble method resulting from the growth of hundreds to thousands of unique regression trees, each of which is created using a bootstrapped sample of the dataset and random subsets of explanatory variables at each node (Breiman 2001, Diesing et al. 2017). Random forest outputs a list of variable importance, determined by permuting each predictor variable and calculating the percentage error increase associated with the change. Higher values correspond to greater variable importance. Variable importance from the random forest was then compared to regression tree outputs. We used a forest with 500 trees and tested 8 randomly selected variables at each split.

\section{RESULTS}

\subsection{Environmental variables}

Differences in mud content $(\%<63 \mu \mathrm{m})$ were apparent between sites (2-way ANOVA $F_{3,24}=333.43$, $\mathrm{p}<0.001$ ), with Lagoon Bay (LB) and Pukapuka (PP) characterised by significantly muddier sediments than the sandier Kawau Bay sites (Motuora [MR] and Motoketekete [MK]; Table 1). A significant difference in percentage mud content was also detected between Kawau Bay sites, with MK exhibiting less silt and clay than MR. Moderate SOM was observed at all locations, with mean SOM ranging from $2.3 \pm$ $0.02 \%$ at LB to $3.4 \pm 0.36 \%$ at PP. Significant differences in chl a content were observed between sites (2-way ANOVA; $\left.F_{3,24}=5.31, \mathrm{p}<0.01\right)$, with LB having higher chl a content than PP and MR.

We observed differences in macrofaunal abundance between sites (2-way ANOVA; $F_{3,24}=8.35$, $\mathrm{p}<0.001$ ), with sandier sediments at MR and MK exhibiting significantly higher macrofaunal abundance per core than PP and LB (Table 1). The total number of species identified per core increased from $10 \pm 0.9$ and $9.5 \pm 1.2$ at the muddier sites $L B$ and $P P$ to $14.5 \pm 1.2$ and $14.5 \pm 1.0$ species at the sandier sites $\mathrm{MR}$ and $\mathrm{MK}$, respectively, indicating an increase in species richness associated with sandier sites. While there was no significant difference in abundance of individual macrofauna present between the 2 sandier sites, a distinct separation in community structure was apparent, with higher numbers of gastropods and amphipods separating MK from MR (Fig. S1). Polychaetes were less abundant and more similar in species composition within the harbour sites. 


\subsection{Net DNF and nutrient fluxes}

The magnitude of $\mathrm{NO}_{\mathrm{x}}{ }^{-}$fluxes measured over the incubation period varied by roughly $100 \mu \mathrm{mol} \mathrm{m}^{-2} \mathrm{~h}^{-1}$ (Fig. 2A), with a net efflux measured in the majority of chambers. $\mathrm{PO}_{4}{ }^{3-}$ fluxes (not shown) varied considerably across chambers, ranging from $-2.26 \pm 8.9$ to $37.61 \pm 16.2 \mu \mathrm{mol} \mathrm{m}{ }^{-2} \mathrm{~h}^{-1}$, and no clear pattern related to the presence of mussels or location. Two-way ANOVA suggested that the effect of mussels on $\mathrm{NH}_{4}{ }^{+}$ fluxes was dependent on location $\left(F_{3,24}=4.82, \mathrm{p}<\right.$ 0.01 ), although post hoc pairwise comparisons were not powerful enough to detect significant pairs of means (Fig. 2B; Table S3). Sediment oxygen demand was significantly higher in chambers with mussels than in chambers without mussels (2-way ANOVA; $\left.F_{1,24}=24.02, \mathrm{p}<0.001\right)$, and this pattern was observed across sites (Fig. 2C).

Net $\mathrm{N}_{2}$ fluxes were highly variable, but were observed on a scale similar to other coastal marine sediments globally (e.g. Seitzinger 1988, O'Meara et al. 2020 and references therein). Net $\mathrm{N}_{2}$ fluxes in chambers without mussels were close to 0 at PP,
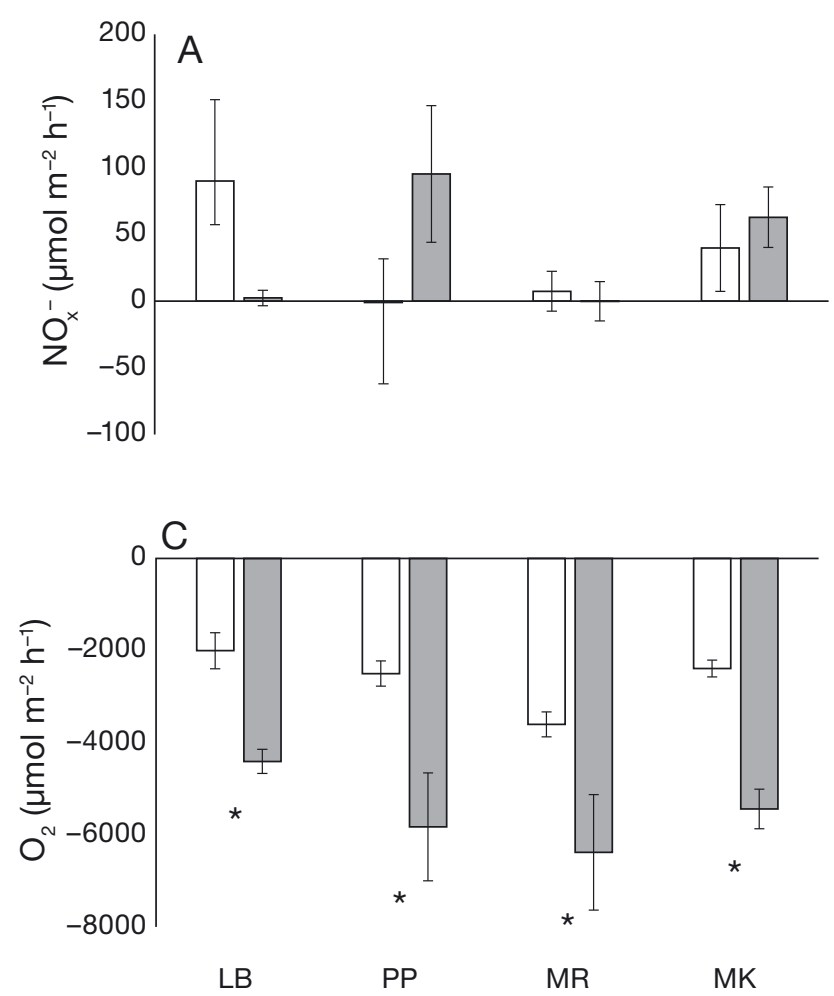

MR, and MK $(33.86 \pm 25.8,42.66 \pm 42.6$, and $94.33 \pm$ $124.1 \mu \mathrm{mol} \mathrm{N} \mathrm{m}{ }^{-2} \mathrm{~h}^{-1}$, respectively). Net nitrogen fixation was apparent in chambers with $(-625.36 \pm$ $\left.292.8 \mu \mathrm{mol} \mathrm{N} \mathrm{m} \mathrm{N}^{-2} \mathrm{~h}^{-1}\right)$ and without $(-768.24 \pm$ $414.3 \mu \mathrm{mol} \mathrm{N} \mathrm{m} \mathrm{N}^{-2} \mathrm{~h}^{-1}$ ) mussels at site LB (Fig. 2D). In chambers containing mussels, highest average sediment DNF rates were recorded at PP (56.82 \pm $40.6 \mu \mathrm{mol} \mathrm{N} \mathrm{m}^{-2} \mathrm{~h}^{-1}$ ). Log-transformed $\mathrm{N}_{2}$ fluxes at LB were significantly different from all other sites (2-way ANOVA $\left.F_{3,24}=10.23, \mathrm{p}<0.001\right)$, and the presence or absence of mussels did not significantly affect these rates (2-way ANOVA $F_{1,24}=0.02, \mathrm{p}=$ $0.883)$. While significant differences were not detected due to the high variance in measurements between chambers, DNF appeared higher in chambers without mussels at the sandiest site (MK), and a net decrease in nitrogen fixation (potentially indicative of DNF) was seen in chambers with mussels at the muddiest site (LB; Fig. 2D).

Regression trees and the random forest algorithm used data from 32 benthic flux chambers that were deemed to have acceptable oxygen levels (nonhypoxic) and small changes in Ar concentration at
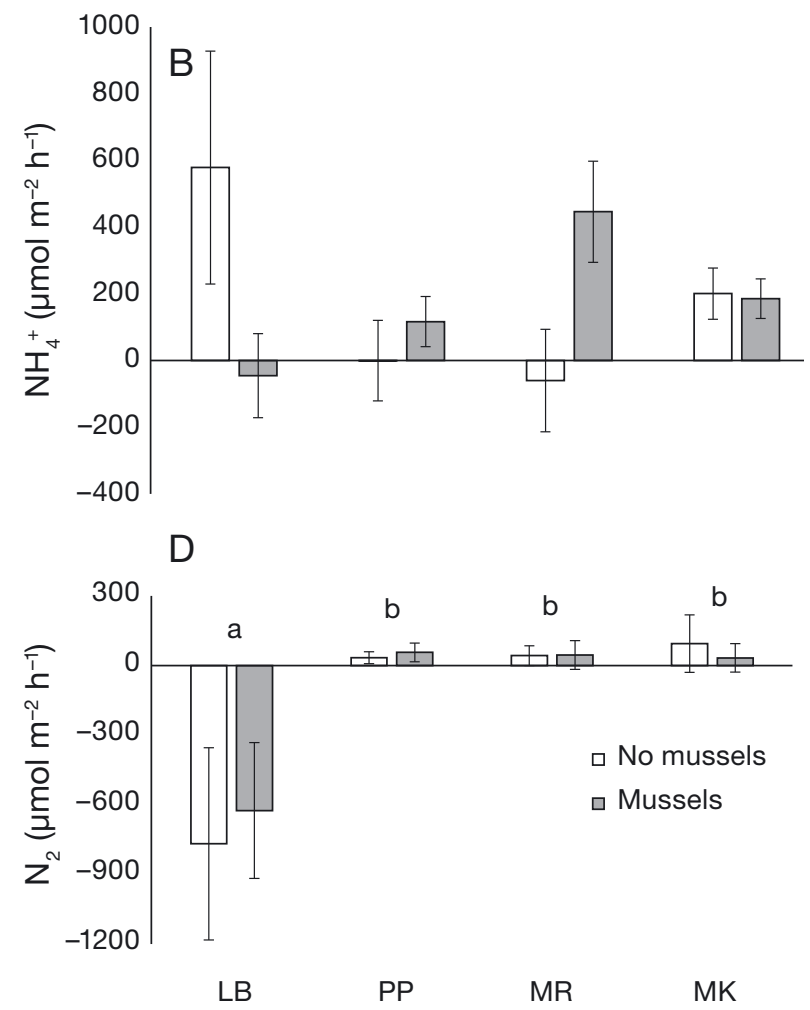

Fig. 2. Net fluxes measured in chambers containing no mussels (white) and mussels (dark) across 4 field sites. (A) Nitrate + nitrite $\left(\mathrm{NO}_{\mathrm{x}}{ }^{-}\right.$) fluxes; (B) $\mathrm{NH}_{4}{ }^{+}$fluxes; (C) benthic oxygen consumption; (D) denitrification (positive) and nitrogen fixation (negative) rates. Note scale differences between graphs. Asterisks indicate significant differences $(p<0.05)$ between chambers with and without mussels, while letters denote significant differences in mean flux rates between sites. Error bars represent SE. Sites are arranged across a decreasing mud gradient. LB: Lagoon Bay; PP: Pukapuka; MR: Motuora; MK: Motoketekete 


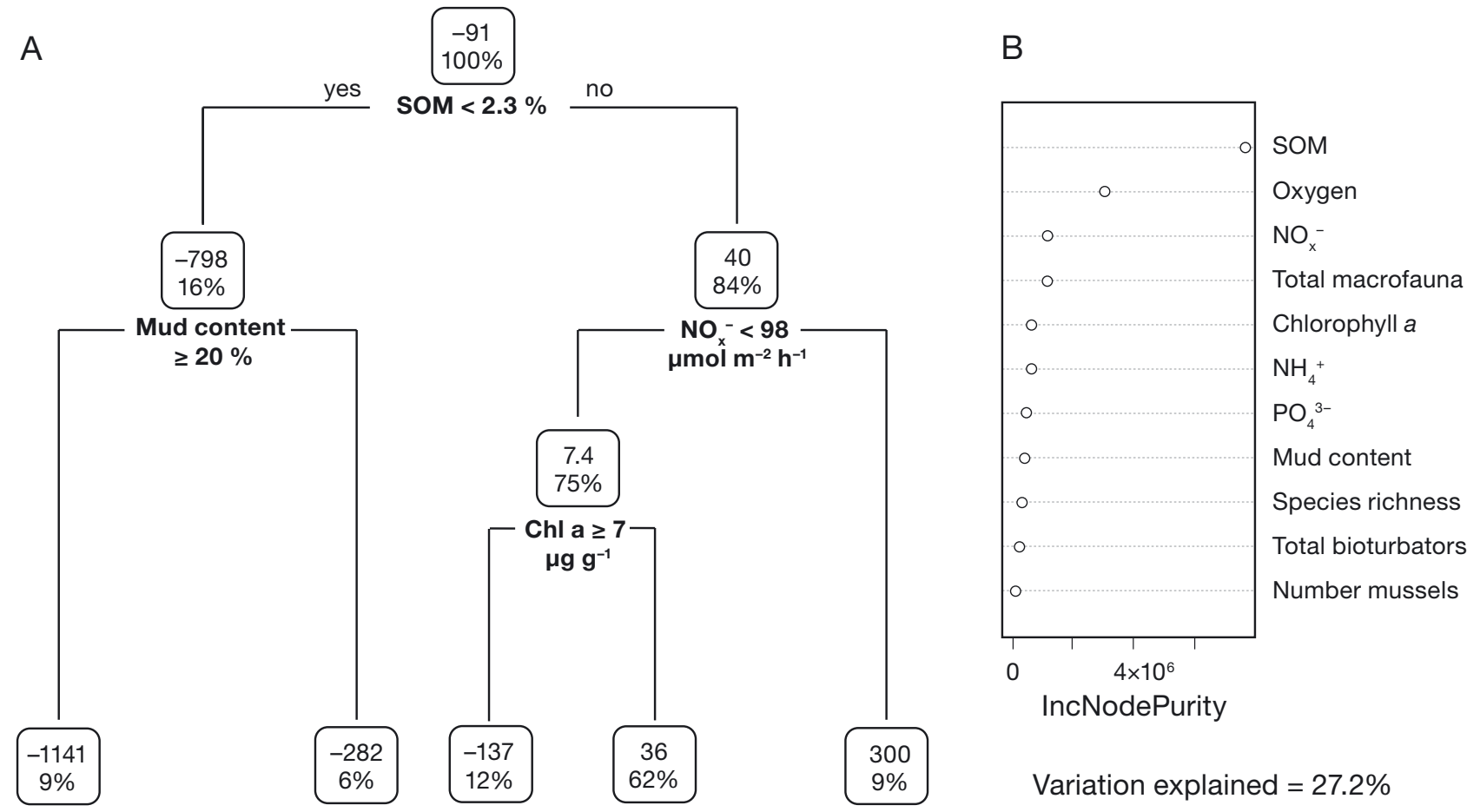

Fig. 3. (A) Single best regression tree predicting denitrification rates in restored mussel beds. Each node highlights the selected environmental variable at its split point (bold), with positive responses separating left, and negative responses separating right further down the tree. Terminal nodes show mean $\mathrm{N}_{2}$ flux $\left(\mu \mathrm{mol} \mathrm{m} \mathrm{m}^{-2} \mathrm{~h}^{-1}\right.$ ) and the percentage of total samples that contribute to the predicted rate. (B) List of decreasing variable importance (from top to bottom) assigned by the random forest, as determined by increase in node purity (IncNodePurity)

the end of the incubation period. Regression tree analysis of $\mathrm{N}_{2}$ fluxes produced a tree with 5 terminal nodes (Fig. 3A). The first branching point split relative to the percentage of SOM present, with chambers containing lower organic material $(<2.3 \%)$ having lower DNF rates (alternatively, higher net nitrogen fixation). From this split, the magnitude of predicted fluxes varied depending on mud content, with greater nitrogen fixation levels apparent in muddier sediments (mud content $\geq 20 \%$ ). In chambers with organic material $>2.3 \%$, greatest DNF rates corresponded to higher $\mathrm{NO}_{\mathrm{x}}{ }^{-}$effluxes. Chambers with lower $\mathrm{NO}_{\mathrm{x}}{ }^{-}$values showed additional branching relative to the concentration of chl $a$, with nitrogen fixation occurring in chambers with higher chl a $\left(\geq 7 \mu \mathrm{g} \mathrm{g}^{-1}\right)$, and DNF occurring in chambers with chl a below this threshold. The random forest was able to explain $27.2 \%$ of the variance in observed nitrogen fluxes and ranked SOM as the most important environmental predictor of nitrogen fluxes, in alignment with the regression tree model. Site, oxygen demand, and total macrofaunal abundance were also identified as influential explanatory variables (Fig. 3B).

\section{DISCUSSION}

In this study, we used benthic flux chambers to show that DNF occurs within restored mussel beds, and that the magnitude and extent of nitrogen removal is dependent on a variety of environmental and biogeochemical factors. As coastal systems are highly heterogeneous in nature, ecosystem services are often generated by complex and interrelated ecosystem processes that vary over space and time; this makes the quantification of nitrogen cycling and other ecosystem services provided by restored mussel beds very challenging. However difficult, it is important to recognise and assign value to these services, as more traditional management schemes have commonly failed to do so and have consequently permitted the degradation of ecosystems in ways that greatly reduce the value of services they provide (e.g. Costanza et al. 1997). The historic collapse of mussel beds in New Zealand (Paul 2012) is one such example, where services other than food provision did not influence the regulation of the fishery.

Multiple studies (e.g. Kellogg et al. 2013, Humphries et al. 2016, Smyth et al. 2018) have shown that 
DNF rates are significantly enhanced in restored bivalve beds; our study is first in building on that knowledge to determine if DNF rates vary at the patch scale within individual beds, and which environmental factors are most significant in explaining variability in measured rates. This in situ study was conducted entirely within restored mussel beds of an oligotrophic coastal ecosystem. Net nitrogen fluxes were similar between chambers with and without mussels (Fig. 2D), suggesting that mussels influence DNF on scales larger than individual clumps, implying a bed-scale phenomenon rather than more localised effects around smaller patches. Measured environmental factors associated with restoration (e.g. enhanced SOM) are better predictors of sediment DNF rates in these systems.

This study highlights the importance of SOM on $\mathrm{N}_{2}$ fluxes, with greater DNF associated with moderate organic matter loading in mussel beds. The importance of SOM in partitioning $\mathrm{N}_{2}$ fluxes in our models, across both chambers with and without mussels, suggests that carbon-rich biodeposits generated by the enhanced benthic-pelagic coupling of restored mussel populations can provide a source of organic material necessary for remineralisation, the products of which $\left(\mathrm{NH}_{4}{ }^{+}, \mathrm{NO}_{2}{ }^{-}\right.$, and $\left.\mathrm{NO}_{3}{ }^{-}\right)$go on to fuel DNF in localised regions of hypoxic sediment (Herbert 1999, Nizzoli et al. 2006). Stimulation of DNF as a result of bivalve biodeposits and increased SOM has been reported elsewhere (e.g. Newell et al. 2002, Newell 2004, Kellogg et al. 2013) and likely contributed to increased nitrogen removal observed in chambers with higher SOM in this study. While we did not detect statistical differences in percentage SOM between chambers with and without mussels, studies using other bivalves in this harbour have documented increased sedimentation rates and organic carbon inputs closer to individuals of the large pinnid bivalve Atrina zelandica (Norkko et al. 2001), reaffirming the idea that bivalve beds retain organic material enriched in carbon and nitrogen. It is possible that the biodeposits created by the smaller greenlipped mussels are not trapped locally but are instead spread over the entire bed. This increased SOM dispersion would account for potential effects at the scale of mussel beds rather than individual clumps and could help explain the similarities in DNF observed between chambers with and without mussels in this study.

Nitrification and DNF are tightly coupled processes at low nitrate concentrations (e.g. Gongol \& Savage 2016, Vieillard et al. 2020), suggesting that the enhanced nitrogen removal capacity resulting from increased SOM observed here may have an upper limit. However, this was not observed at organic matter loads present in our beds. In our oligotrophic system, we conclude that highest DNF rates will be achieved with moderate organic matter enrichment, as insufficient SOM will limit ammonification and nitrate production, and excessive SOM will result in higher oxygen demand and the potential production of sulfides (e.g. Christensen et al. 2003) which would further inhibit these processes (Joye \& Hollibaugh 1995). These relationships are mirrored in the conceptual models of others (Hoellein \& Zarnoch 2014) who predicted that the role of bivalve biodeposition on DNF will have the greatest effect in oligotrophic systems, as bivalves likely stimulate coupled nitrification-DNF (as opposed to ammonium immobilisation in eutrophic systems high in sediment organic carbon), and competition for nitrate (shown to be important in regression tree outputs) is reduced in low-nutrient environments. Even if competition is reduced in these systems, both regression tree and random forest models indicate the importance of $\mathrm{NO}_{\mathrm{x}}{ }^{-}$effluxes from chamber incubations on DNF rates, with higher $\mathrm{NO}_{\mathrm{x}}{ }^{-}$availability corresponding to maximum nitrogen removal. It is likely that the nitrogenous products of organic matter mineralisation (resulting from biodeposits and mussels themselves) supply the $\mathrm{NO}_{\mathrm{x}}{ }^{-}$necessary to fuel eventual nitrogen removal, and that the coupling of nitrification and DNF is important in these epifaunal mussel beds.

When $\mathrm{NO}_{\mathrm{x}}^{-}$levels measured during incubations were low, chl a content influenced whether nitrogen fixation or DNF took place, with higher chlorophyll levels associated with nitrogen fixation and lower chl a levels associated with DNF. This suggests a weak yet negative influence of local MPB communities on sediment DNF possibly due to competition for nitrogen (also noted by O'Meara et al. 2020). MPB are known to reduce nutrient fluxes across the sedimentwater interface as a result of nutrient uptake necessary for their growth and survival, and the sticky polymers produced by MPB can alter sediment cohesion (Newell et al. 2002, Hope et al. 2020); together, these actions result in the reduction of solute transport and could help explain lower predicted DNF rates in regression tree outputs. The influence of MPB was not expected as experiments were carried out under dark conditions; however, others have shown that nutrient uptake by MPB continues in the dark (Rysgaard et al. 1993, Evrard et al. 2008, Ni Longphuirt et al. 2009), and this dark ammonium uptake was observed at 3 of our field sites. MPB are 
capable of outcompeting nitrifiers and denitrifiers for dissolved inorganic nitrogen (Newell et al. 2002, Sundbäck \& Miles 2002, Cook et al. 2004), and appear to do so when found at higher concentrations in these systems. As all fluxes in our study were measured under dark conditions, it should be noted that these results reflect an approximation of maximum DNF potential under no-light conditions. The presence of light would likely enhance nutrient uptake by MPB, but would also increase oxygen availability as a result of photosynthesis (potentially available for further nitrification which is then coupled to DNF); it would be useful in the future to measure and balance these fluxes over a diel cycle in order to upscale nitrogen removal rates on restored mussel beds. In addition, active epibenthos such as bivalves can respond rapidly to changes in their environment (e.g. fluctuations in suspended sediment and phytoplankton concentrations; Higgins 1980, Ward \& MacDonald 1996). Future studies linking changes in environmental conditions to Perna canaliculus behaviour could further our understanding of how bivalves affect nitrogen dynamics at larger spatial and temporal scales.

Our flux measurement incubation period represents one point in time. While ambient inorganic nitrogen concentrations and measured fluxes have not shown substantial seasonality in northern New Zealand (Jones et al. 2011, Tay et al. 2012), temporal variation was not addressed in the current study. These scale constraints are common with field-based research and suggest that any information used from this study to inform the placement of future beds be nested in an adaptive management framework to reevaluate the success of mussel restoration projects on nitrogen removal over longer timescales.

In the present study, net DNF increased with decreasing mud content, and these results are mirrored by others who have carried out benthic chamber experiments in the same harbour (O'Meara et al. 2020). The regression tree suggests that percentage mud content becomes most important at low levels of SOM $(<2.3 \%)$. It should be noted that the terminal nodes associated with this split both result in apparent nitrogen fixation, yet this rate decreases with decreasing mud content. Grain size affects the transport of nutrients into and out of marine sediments, and larger particle size typically corresponds to higher porosity associated with increased porewater advection and the transport of nutrients (Santos et al. 2012). At low organic matter loads, mussel biodeposits make a greater contribution to DNF in more permeable, nutrient-poor sediments, increasing the availability of bioreactive nitrogen while creating anoxic microsites required for DNF (Seitzinger et al. 2006). It is also well documented that macrofaunal abundance and species richness increase with decreasing mud content (e.g. Mannino \& Montagna 1997, Thrush et al. 2003, 2004, Pratt et al. 2014) and that macrofauna stimulate increased nitrogen removal (reviewed by Stief 2013). Given these relationships, it follows that DNF increases with decreasing mud content, as the abundance of these sedimentdwelling species also increases under these circumstances. While not emphasised by regression tree analysis, the significance of macrofaunal abundance as an important variable was reflected in random forest outputs.

Of notable interest are the net fluxes at site LB, where net nitrogen fixation was apparent in all chambers. Nitrogen fixation (breaking the dinitrogen triple bond) is an energetically costly process. Even in the presence of bivalves that emit nitrogenous compounds, it is clear that a demand for bioavailable nitrogen exists at $\mathrm{LB}_{\text {; }}$ this nitrogen demand is perhaps not surprising for a low-nutrient system, and nitrogen fixation has previously been recorded in other bivalve studies (Humphries et al. 2016) and under dark conditions (Fulweiler et al. 2007). Cyanobacteria known to produce nitrogenase (the enzyme responsible for reducing $\mathrm{N}_{2}$ to ammonia) have been found in local estuarine sediments of this region (Hicks \& Silvester 1985) and could account for observed nitrogen fixation. At $\mathrm{LB}, \mathrm{NO}_{\mathrm{x}}{ }^{-}$and $\mathrm{NH}_{4}{ }^{+}$emissions in chambers without mussels possibly reflect the products of microbial nitrogen fixation; lower $\mathrm{NO}_{\mathrm{x}}{ }^{-}$and $\mathrm{NH}_{4}{ }^{+}$fluxes observed in chambers with mussels suggest tight recycling/high turnover of nitrogen in these places. In many oligotrophic environments, a larger percentage of total bioreactive nitrogen is assimilated rather than removed as $\mathrm{N}_{2}$ gas; this increased nitrogen retention, however, can support increased secondary and tertiary production (Cook et al. 2004, Vieillard et al. 2020).

Understanding nitrogen dynamics in oligotrophic environments is crucial, as these systems are highly underrepresented in the literature (Vieillard et al. 2020) and restoration projects in these places likely differ in their capacity to support enhanced nitrogen removal services (Hoellein \& Zarnoch 2014). In such a system, we conclude that the effects of mussel restoration on sediment DNF are not restricted to the patch-scale, and that dispersed SOM is an important predictor of net $\mathrm{N}_{2}$ fluxes at restoration sites. This study contributes to the small but growing literature base on nitrogen cycling in oligotrophic estuaries of 
the southern hemisphere, with project insights helping us better understand ecosystem functionality in restored bivalve systems.

Acknowledgements. We thank Al Alder, Brady Doak, Caitlin Blain, Craig Norrie, Eliana Ferretti, Kaiwen Yang, and Stefano Schenone for their help with field work, and Maria Mugica and Julie Hope for their assistance in the laboratory. Special thanks to Amanda Vieillard, Stefano Bonaglia, Teri O'Meara, and Rebecca Gladstone-Gallagher for contentspecific advice and to Judi Hewitt and Marco Colossi Brustolin for help with statistical analysis. We greatly appreciate recommendations from 3 anonymous reviewers which improved the overall quality of the manuscript. This project was supported by Fulbright New Zealand, George Mason Centre for the Natural Environment, Gulf Innovation Fund Together at Foundation North, and a University of Auckland Doctoral Scholarship to M.A.S.

\section{LITERATURE CITED}

Anderson DM, Glibert PM, Burkholder JM (2002) Harmful algal blooms and eutrophication: nutrient sources, composition, and consequences. Estuaries 25:704-726

Balemi A, Chandra D, Curran J, Deppa B and others (2021) s20x: Functions for University of Auckland Course STATS 201/208 Data Analysis. R package version 3.1-30. https://CRAN.R-project.org/package $=$ s20x

Ball D (1964) Loss-on-ignition as an estimate of organic matter and organic carbon in non-calcareous soils. J Soil Sci 15:84-92

Breiman L (2001) Random forests. Mach Learn 45:5-32

Carlsson MS, Engström P, Lindahl O, Ljungqvist L, Petersen JK, Svanberg L, Holmer M (2012) Effects of mussel farms on the benthic nitrogen cycle on the Swedish west coast. Aquacult Environ Interact 2:177-191

Cerco CF, Noel MR (2007) Can oyster restoration reverse cultural eutrophication in Chesapeake Bay? Estuaries Coasts 30:331-343

Christensen PB, Glud RN, Dalsgaard T, Gillespie P (2003) Impacts of longline mussel farming on oxygen and nitrogen dynamics and biological communities of coastal sediments. Aquaculture 218:567-588

Commito JA, Dankers NMJA (2001) Dynamics of spatial and temporal complexity in European and North American soft-bottom mussel beds. In: Reise K (ed) Ecological comparisons of sedimentary shores. Ecological Studies (Analysis and Synthesis), Vol 151. Springer, Berlin, p 39-59

Cook AE, Shaffer JA, Dumbauld BR (2000) A plan for rebuilding stocks of Olympia oysters (Ostreola conchaphila, Carpenter 1857) in Washington state. J Shellfish Res 19:409-412

* Cook PLM, Revill AT, Butler ECV, Eyre BD (2004) Carbon and nitrogen cycling on intertidal mudflats of a temperate Australian estuary. II. Nitrogen cycling. Mar Ecol Prog Ser 280:39-54

* Costanza R, d'Arge R, de Groot R, Farber S and others (1997) The value of the world's ecosystem services and natural capital. Nature 387:253-260

Dame RF (2012) Ecology of marine bivalves: an ecosystem approach. Taylor \& Francis, Boca Raton, FL

* De'ath G, Fabricius KE (2000) Classification and regression trees: a powerful yet simple technique for ecological data analysis. Ecology 81:3178-3192

Diaz RJ, Rosenberg R (2008) Spreading dead zones and consequences for marine ecosystems. Science 321:926-929

* Diesing M, Kröger S, Parker R, Jenkins C, Mason C, Weston K (2017) Predicting the standing stock of organic carbon in surface sediments of the North-West European continental shelf. Biogeochemistry 135:183-200

* Douglas EJ, Pilditch CA, Kraan C, Schipper LA, Lohrer AM, Thrush SF (2017) Macrofaunal functional diversity provides resilience to nutrient enrichment in coastal sediments. Ecosystems 20:1324-1336

* Evans JS, Cushman SA (2009) Gradient modeling of conifer species using random forests. Landsc Ecol 24:673-683

* Evrard V, Cook PLM, Veuger B, Huettel M, Middelburg JJ (2008) Tracing carbon and nitrogen incorporation and pathways in the microbial community of a photic subtidal sand. Aquat Microb Ecol 53:257-269

* Eyre BD, Rysgaard S, Dalsgaard T, Christensen PB (2002) Comparison of isotope pairing and $\mathrm{N}_{2}$ :Ar methods for measuring sediment denitrification - assumptions, modifications, and implications. Estuaries 25:1077-1087

Fyre BD, Maher DT, Squire P (2013) Quantity and quality of organic matter (detritus) drives $\mathrm{N}_{2}$ effluxes (net denitrification) across seasons, benthic habitats, and estuaries. Global Biogeochem Cycles 27:1083-1095

* Fulweiler RW, Nixon SW, Buckley BA, Granger SL (2007) Reversal of the net dinitrogen gas flux in coastal marine sediments. Nature 448:180-182

Galloway JN, Aber JD, Erisman JW, Seitzinger SP, Howarth RW, Cowling EB, Cosby BJ (2003) The nitrogen cascade. Bioscience 53:341-356

*Galloway JN, Dentener FJ, Capone DG, Boyer EW and others (2004) Nitrogen cycles: past, present, and future. Biogeochemistry 70:153-226

Galloway JN, Townsend AR, Erisman JW, Bekunda M and others (2008) Transformation of the nitrogen cycle: recent trends, questions, and potential solutions. Science 320:889-892

Gongol C, Savage C (2016) Spatial variation in rates of benthic denitrification and environmental controls in four New Zealand estuaries. Mar Ecol Prog Ser 556:59-77

*Hawkins AJS, James MR, Hickman RW, Hatton S, Weatherhead M (1999) Modelling of suspension-feeding and growth in the green-lipped mussel Perna canaliculus exposed to natural and experimental variations of seston availability in the Marlborough Sounds, New Zealand. Mar Ecol Prog Ser 191:217-232

*Herbert RA (1999) Nitrogen cycling in coastal marine ecosystems. FEMS Microbiol Rev 23:563-590

*Hicks BJ, Silvester WB (1985) Nitrogen fixation associated with the New Zealand mangrove (Avicennia marina (Forsk.) Vierh. var. resinifera (Forst. f.) Bakh.). Appl Environ Microbiol 49:955-959

* Higgins PJ (1980) Effects of food availability on the valve movements and feeding behavior of juvenile Crassostrea virginica (Gmelin). I. Valve movements and periodic activity. J Exp Mar Biol Ecol 45:229-244

Hoellein TJ, Zarnoch CB (2014) Effect of eastern oysters (Crassostrea virginica) on sediment carbon and nitrogen dynamics in an urban estuary. Ecol Appl 24:271-286

* Hope JA, Paterson DM, Thrush SF (2020) The role of microphytobenthos in soft-sediment ecological networks and their contribution to the delivery of multiple ecosystem services. J Ecol 108:815-830 
Hou L, Zheng Y, Liu M, Li X and others (2015) Anaerobic ammonium oxidation and its contribution to nitrogen removal in China's coastal wetlands. Sci Rep 5:15621

*Howarth RW, Marino R (2006) Nitrogen as the limiting nutrient for eutrophication in coastal marine ecosystems: evolving views over three decades. Limnol Oceanogr 51: 364-376

Humphries AT, Ayvazian SG, Carey JC, Hancock BT and others (2016) Directly measured denitrification reveals oyster aquaculture and restored oyster reefs remove nitrogen at comparable high rates. Front Mar Sci 3:74

Iglesias JIP, Urrutia MB, Navarro E, Alvarez-Jorna P, Larretxea X, Bougrier S, Heral M (1996) Variability of feeding processes in the cockle Cerastoderma edule (L.) in response to changes in seston concentration and composition. J Exp Mar Biol Ecol 197:121-143

Jones HF, Pilditch CA, Bruesewitz DA, Lohrer AM (2011) Sedimentary environment influences the effect of an infaunal suspension feeding bivalve on estuarine ecosystem function. PLOS ONE 6:e27065

Joye SB, Hollibaugh JT (1995) Influence of sulfide inhibition of nitrification on nitrogen regeneration in sediments. Science 270:623-625

Kana TM, Darkangelo C, Hunt MD, Oldham JB, Bennett GE, Cornwell JC (1994) Membrane inlet mass spectrometer for rapid high-precision determination of $\mathrm{N}_{2}, \mathrm{O}_{2}$, and $\mathrm{Ar}$ in environmental water samples. Anal Chem 66:4166-4170

Kellogg ML, Cornwell JC, Owens MS, Paynter KT (2013) Denitrification and nutrient assimilation on a restored oyster reef. Mar Ecol Prog Ser 480:1-19

Kirby MX (2004) Fishing down the coast: historical expansion and collapse of oyster fisheries along continental margins. Proc Natl Acad Sci USA 101:13096-13099

Kuypers MM, Marchant HK, Kartal B (2018) The microbial nitrogen-cycling network. Nat Rev Microbiol 16:263-276

Liaw A, Wiener M (2002) Classification and regression by randomForest. $\mathrm{R}$ News 2:18-22

Lohrer AM, Thrush SF, Gibbs MM (2004) Bioturbators enhance ecosystem function through complex biogeochemical interactions. Nature 431:1092-1095

Lorenzen CJ (1967) Determination of chlorophyll and pheo-pigments: spectrophotometric equations. Limnol Oceanogr 12:343-346

Mannino A, Montagna PA (1997) Small-scale spatial variation of macrobenthic community structure. Estuaries 20: 159-173

* McLeod IM, Parsons DM, Morrison MA, Le Port A, Taylor RB (2012) Factors affecting the recovery of soft-sediment mussel reefs in the Firth of Thames, New Zealand. Mar Freshw Res 63:78-83

Middelburg JJ, Soetaert K, Herman PMJ, Heip CHR (1996) Denitrification in marine sediments: a model study. Global Biogeochem Cycles 10:661-673

Newell RIE (2004) Ecosystem influences of natural and cultivated populations of suspension-feeding bivalve molluscs: a review. J Shellfish Res 23:51-61

Newell RIE, Cornwell JC, Owens MS (2002) Influence of simulated bivalve biodeposition and microphytobenthos on sediment nitrogen dynamics: a laboratory study. Limnol Oceanogr 47:1367-1379

Ni Longphuirt S, Lim JH, Leynaert A, Claquin P, Choy EJ, Kang CK, An S (2009) Dissolved inorganic nitrogen uptake by intertidal microphytobenthos: nutrient concentrations, light availability and migration. Mar Ecol Prog Ser 379:33-44
Nixon SW (1998) Enriching the sea to death. Sci Am 9:48-53

* Nizzoli D, Welsh DT, Fano EA, Viaroli P (2006) Impact of clam and mussel farming on benthic metabolism and nitrogen cycling, with emphasis on nitrate reduction pathways. Mar Ecol Prog Ser 315:151-165

Norkko A, Hewitt JE, Thrush SF, Funnell T (2001) Benthicpelagic coupling and suspension-feeding bivalves: linking site-specific sediment flux and biodeposition to benthic community structure. Limnol Oceanogr 46:2067-2072

* O'Meara TA, Hewitt JE, Thrush SF, Douglas EJ, Lohrer AM (2020) Denitrification and the role of macrofauna across estuarine gradients in nutrient and sediment loading. Estuaries Coasts 43:1394-1405

Olito C, White CR, Marshall DJ, Barneche DR (2017) Estimating monotonic rates from biological data using local linear regression. J Exp Biol 220:759-764

Paerl HW (1997) Coastal eutrophication and harmful algal blooms: importance of atmospheric deposition and groundwater as 'new' nitrogen and other nutrient sources. Limnol Oceanogr 42:1154-1165

Paul LJ (2012) A history of the Firth of Thames dredge fishery for mussels: use and abuse of a coastal resource. New Zealand Aquatic Environment and Biodiversity Report 94. Ministry of Agriculture and Forestry, Wellington

* Peterson CH, Irlandi EA, Black R (1994) The crash in suspension-feeding bivalve populations (Katelysia spp.) in Princess Royal Harbour: an unexpected consequence of eutrophication. J Exp Mar Biol Ecol 176:39-52

* Piehler MF, Smyth AR (2011) Habitat-specific distinctions in estuarine denitrification affect both ecosystem function and services. Ecosphere 2:art12

* Pratt DR, Lohrer AM, Pilditch CA, Thrush SF (2014) Changes in ecosystem function across sedimentary gradients in estuaries. Ecosystems 17:182-194

Prins TC, Small AC, Dame RF (1998) A review of the feedbacks between bivalve grazing and ecosystem processes. Aquat Ecol 31:349-359

*Quintana CO, Tang M, Kristensen E (2007) Simultaneous study of particle reworking, irrigation transport and reaction rates in sediment bioturbated by the polychaetes Heteromastus and Marenzelleria. J Exp Mar Biol Ecol 352: 392-406

R Core Team (2019) R: a language and environment for statistical computing. R Foundation for Statistical Computing, Vienna

* Ray DG, Cahalan GD, Lendemer JC (2020) Factors influencing the persistence of reindeer lichens (Cladonia subgenus Cladina) within frequent-fire environments of the Mid-Atlantic coastal plain, USA. Fire Ecol 16:1

* Rich JJ, Dale OR, Song B, Ward BB (2008) Anaerobic ammonium oxidation (anammox) in Chesapeake Bay sediments. Microb Ecol 55:311-320

* Rysgaard S, Risgaard-Petersen N, Nielsen LP, Revsbech NP (1993) Nitrification and denitrification in lake and estuarine sediments measured by the ${ }^{15} \mathrm{~N}$ dilution technique and isotope pairing. Appl Environ Microbiol 59:2093-2098

Santos IR, Eyre BD, Huettel M (2012) The driving forces of porewater and groundwater flow in permeable coastal sediments: a review. Estuar Coast Shelf Sci 98:1-15

Seitzinger SP (1988) Denitrification in freshwater and coastal marine ecosystems: ecological and geochemical significance. Limnol Oceanogr 33:702-724

Seitzinger S, Harrison JA, Böhlke JK, Bouwman AF and others (2006) Denitrification across landscapes and waterscapes: a synthesis. Ecol Appl 16:2064-2090 
Smith DiCarlo LA, DeBano SJ, Burrows S (2020) Arid grassland bee communities: associated environmental variables and responses to restoration. Restor Ecol 28:A54-A64

Smyth AR, Murphy AE, Anderson IC, Song B (2018) Differential effects of bivalves on sediment nitrogen cycling in a shallow coastal bay. Estuaries Coasts 41:1147-1163

Stief P (2013) Stimulation of microbial nitrogen cycling in aquatic ecosystems by benthic macrofauna: mechanisms and environmental implications. Biogeosciences 10:7829-7846

Sundbäck K, Miles A (2002) Role of microphytobenthos and denitrification for nutrient turnover in embayments with floating macroalgal mats: a spring situation. Aquat Microb Ecol 30:91-101

Tay HW, Bryan KR, Pilditch CA, Park S, Hamilton DP (2012) Variations in nutrient concentrations at different time scales in two shallow tidally dominated estuaries. Mar Freshw Res 63:95-109

Therneau T, Atkinson B (2019). rpart: Recursive Partitioning and Regression Trees. R package version 4.1-15. https:// CRAN.R-project.org/package=rpart

Thrush SF, Hewitt JE, Norkko A, Nicholls PE, Funnell GA, Ellis JI (2003) Habitat change in estuaries: predicting broad-scale responses of intertidal macrofauna to sediment mud content. Mar Ecol Prog Ser 263:101-112

Editorial responsibility: Robinson Fulweiler, Boston, Massachusetts, USA

Reviewed by: G. Banta, F. Roth and 1 anonymous referee
* Thrush S, Hewitt J, Cummings V, Ellis J, Hatton C, Lohrer A, Norkko A (2004) Muddy waters: elevating sediment input to coastal and estuarine habitats. Front Ecol Environ 2:299-306

Thrush SF, Townsend M, Hewitt JE, Davies K and others (2013) The many uses and values of estuarine ecosystems. Ecosystem services in New Zealand-conditions and trends. Manaaki Whenua Press, Lincoln

* Thrush SF, Hewitt JE, Gladstone-Gallagher RV, Savage C and others (2021) Cumulative stressors reduce the selfregulating capacity of coastal ecosystems. Ecol Appl 31: e02223

* Vieillard AM, Newell SE, Thrush SF (2020) Recovering from bias: a call for further study of underrepresented tropical and low-nutrient estuaries. J Geophys Res Biogeosci 125: e2020JG005766

Ward EJ, MacDonald BA (1996) Pre-ingestive feeding behaviors of two sub-tropical bivalves (Pinctada imbricata and Arca zebra): responses to an acute increase in suspended sediment concentration. Bull Mar Sci 59: 417-432

zu Ermgassen PSE, Thurstan RH, Corrales J, Alleway H and others (2020) The benefits of bivalve reef restoration: a global synthesis of underrepresented species. Aquat Conserv 30:2050-2065

Submitted: August 27, 2020

Accepted: April 13, 2021

Proofs received from author(s): May 29, 2021 